\title{
Empreendedorismo, inovação e captação de recursos
}

Newton M. Campos | newton.campos@faculty.ie.edu

Empreendedorismo tornou-se uma “disciplina” há pouco tempo. Foi apenas com o início da globalização do sistema de mercado e com o advento da internet que o fenômeno começou a ficar evidente como relevante para os processos de inovação social e econômica. Os empreendedores, não como simples fundadores de organizações, mas principalmente como inovadores em ação, vêm, assim, ganhando ares de estrelas da economia mundial. 0 assunto passou a interessar a pessoas de diversas idades e classes sociais, trazendo o foco do processo para o principal problema enfrentado por potenciais empreendedores: a captação de recursos. Por sua natureza multidisciplinar, o assunto pode ser abordado desde inúmeras óticas, das quais o professor Newton M. Campos (IE Business School e FGV-EAESP) prefere pesquisar aquelas com vieses práticos e aplicáveis em economias emergentes.
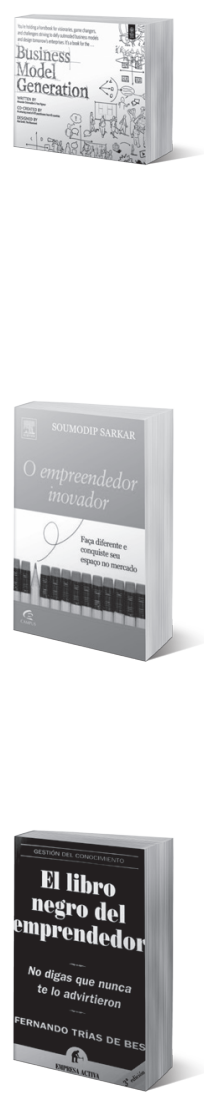

\section{EL LIBRO NEGRO DEL EMPRENDEDOR: No digas que nunca te lo advirtieron} Fernando Trías de Bes. Barcelona: Empresa Activa (Ed. Urano) 2007. 192 p.

Este livro aborda o empreendedor de uma ótica diferenciada: ao invés de partir dos empreendedores bem-sucedidos, o professor Fernando Trías de Bes pesquisa os mais de $90 \%$ de empreendedores em potencial cujos empreendimentos não chegaram sequer ao quarto ano de vida. 0 autor desmistifica, assim, o valor da ideia inicial para o êxito de um empreendimento, creditando à automotivação, à flexibilidade e ao improviso o aumento da sua chance de sobrevivência.

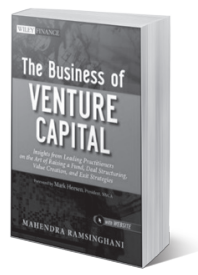

\section{THE BUSINESS OF VENTURE CAPITAL: Insights from leading} practitioners on the art of raising a fund, deal structuring, value creation, and exit strategies

Mahendra Ramsinghani. New Jersey: John Wiley \& Sons, 2011. 432 p.

Com a crescente necessidade de profissionalização do mercado investidor nas economias em desenvolvimento, o livro do professor Mahendra Ramsinghani consegue desmistificar o papel dos fundos de Venture Capital no processo empreendedor, enquanto revela em detalhes o funcionamento desta modalidade de investimento e captação de recursos nos Estados Unidos. O livro mostra-se uma fonte atualizada do que se espera de um projeto para que ele atraia recursos de terceiros.

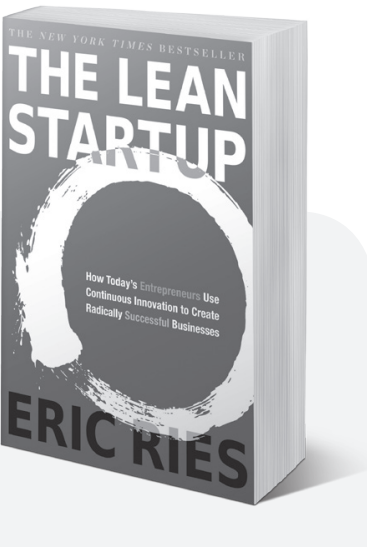

THE LEAN STARTUP: How today's entrepreneurs use continuous innovation to create radically successful businesses

Eric Ries. New York: Crown Business, 2011. 336 p.

Deslocando o foco do processo empreendedor para a execução no lugar do planejamento, esta publicação enfraqueceu ainda mais a importância dos planos de negócio para investidores e empreendedores em potencial. Eric Ries, até então um popular blogueiro sobre o assunto, tornou-se autor de um método que, embora nem um pouco científico (seu "Lean" nada tem a ver com o "Lean Manufacturing”, por exemplo), trouxe conceitos extremamente interessantes para o mundo real do empreendimento. 